\title{
Beginnings of Landscape Architecture in Poland
}

\author{
Agata Zachariasz, Cracow University of Technology, Poland
}

\begin{abstract}
The article describes the period from the end of the nineteenth century to the 1950 's. It presents the achievements of the pioneers of Polish landscape architecture, associated with various aspects of the design, planning and protection of the landscape, in addition to professional education.

In the majority of European countries, the development of landscape architecture as a separate profession is dated to the interbellum period. In Poland there is currently no doubt as to the fact that landscape architecture is an independent professional discipline. However, several decades ago this topic was the subject of spirited discussion among Polish specialists, which took place on the pages of specialist periodicals. The discussions that took place at the time between outstanding garden planners, practitioners, scientists, didactics and popularisers who came from various different fields concerned the profession and the preparation of specialists, in addition to the name itself. One of the pioneers - Zygmunt Hellwig, wrote: "I believe that the shaping of the landscape is an art and science that is currently completely independent, one that has grown equally well from the foundations of horticulture, architecture and a number of similar disciplines, one that can absolutely no longer fit within the framework of the professional preparation and qualifications of an architect-builder."(1935). The landscape architecture profession developed very dynamically. Significant projects, now considered icons, were being developed, e.g. Żelazowa Wola, a monument park dedicated to Chopin or Skaryszewski Park in Warsaw. At horticultural fairs one of the more important sections was garden planning, where individual cities prided themselves in their achievements in the design of public parks. University education started to be provided in this speciality. Franciszek Krzywda-Polkowski, who had obtained an education in architecture, was the first to introduce landscape architecture to a university curriculum and organised and supervised the Landscape Architecture and Park Science Division at the University of Life Sciences starting from 1928. He also taught at the Warsaw University of Technology. His diploma candidates, Alina Scholtz and Gerard Ciołek, made significant contributions to the development of landscape architecture in Poland. A. Scholtz, an outstanding designer, became one of the founding members of the International Federation of Landscape Architecture (IFLA) in 1948. G. Ciolek was the creator of the Polish school of the revalorisation of historical garden layouts. His comprehensive scientific works on the history of garden design had a pioneering character. He is the author of the fundamental work Ogrody polskie (1954).
\end{abstract}

Keywords: landscape design, development of profession, landscape education

\section{Introduction}

In most countries of Europe the development of landscape architecture as an independent discipline took place during the interwar period. No one in Poland currently has any doubt that it is indeed a separate professional specialisation, which has, since the middle of the nineteenth century, changed the image of many cities, focusing on beautiful surroundings, harmonious space and satisfying the need for recreation. However, several decades ago, as far back as in partition-era Poland and after 1918, when the country regained its independence, this subject caused heated debates among specialists. Discussions that went on between outstanding garden planners, practitioners, researchers, educators and popularisers from various fields pertained to the profession itself and the preparing of specialists, as well as to the name itself [48]. Polemics were exchanged on the pages of the contemporary press, while the profession itself enjoyed dynamic development. One of the most important sections at garden fairs was garden planning, in which each city boasted of its achievements in terms of designing public parks and areas of greenery, in which architects, urban and garden planners played a significant role. Sites like parks and squares, the surroundings of institutions or memorials were established. The regaining of independence by Poland in 1918 was conducive to the development of public areas, with sites that highlighted national identity often expressed through the language of designbeing built. Modernism was often making itself seen. The perspectives of the well-developing discipline were shattered by the Second World War and the long period of the elimination of landscape architects from both participating in designing Polish space and the landscape and university education. Since 1995, on the basis of the Ordinance of the Minister of Employment and Social Policy, "Landscape Architects" have been on the list of professions and included in group "216. Architects, surveyors and designers", and marked with the symbol "2162". The consequence of this decision has been the opening of Master's level studies courses at several state and private universities. A review of contemporary curricula in Poland shows that landscape architecture is an interdisciplinary field and its pedigree is usually associated with a given university's specialisation - be it agricultural, technical or artistic. 
The basis for the deliberations contained in this article were Polish publications in which works of landscape architecture had been presented. Due to the interdisciplinary character of the specialisation, as well as the formation of the scope of its activities, the works focus on horticulture, architecture, urban design and environmental protection. They include specialist and popular publications that were issued from the second half of the nineteenth century up to the year 1939 and during the first years after the Second World War, as well as handbooks on garden design and gardening fair reports and guides. Their large number proves that it was an important and popular subject. Periodicals, mainly monthlies and bi-weeklies, were published, including "Ogrodnik Polski" (1879-1905, Warsaw), "Ogrodnik" (1911-1939, Warsaw), "Ogrodnictwo" (1897, Krakow), "Przegląd Ogrodniczy" (Lviv 19221939; Warsaw 1946-1961), "Miesięcznik Ogrodniczy" (1919-1922), "Gospodarz" (1902-1915, Warsaw), "Ogrodnik zawodowy" (1900-1903, Lviv), "Rocznik Polskiego Towarzystwa Dendrologicznego" (1927-1939, Lviv), as well as "Architekt" (1903-1929), "Czasopismo Techniczne" (1883-1939, Lviv), "Dom, Osiedle, Mieszkanie" (1929-1948, Warsaw; previously as "Osiedle, Dom, Mieszkanie"), and "Architektura i Budownictwo" (1925-1939, Warsaw). Periodicals propagating the subject matter of landscape architecture focused on two fundamental disciplines: gardening and architectural and urban design. They of course discussed the full spectrum of subjects typical for the disciplines. However, for the landscape architecture specialisation, the important ones in terms of gardening were, in particular: garden planning, the types of gardens and parks, aesthetics and styles, matters of design. Similarly, in the other group, closer to architecture and urban planning, here these were primarily: parks and public spaces, sports grounds, the greenery of housing estates, the surroundings of the home, areas of urban greenery, ranging from the scale of the detail to that of planning. The publications published texts by specialists, scholars and designers.

The education of gardeners and garden planners in Poland took place both domestically and abroad, often through practical training. Teaching traditions reach back to private gardening schools established by wealthy landowners, with the school in Medyka at the Pawlikowski family estate, at which a four-year course under the supervision of the Czech gardener Józef Blaszek was establsihed in 1835, being a prominent one. In partition-era Poland there were several such schools. 1855 saw the founding of a gardening school in Galicia, in Lviv, at the city's botanical garden, although it operated only briefly and left no lasting impact on gardening. In 1868, in the Prussian partition, Gustav Stoll founded the Pomological Institute in Prószków, in Silesia, with the school's higher department being relocated in 1878 to the University in Wrocław. In Warsaw, in the Russian partition, there functioned a gardening school founded by, among others, Jerzy Alexandrowicz and Piotr Hoser. The Warsaw Garden Society was established in 1884 in this circle as well. In 1913 the Society of Scientific Courses in Warsaw opened its Gardening Faculty, with Piotr F. Hoser as dean. In 1916 the Faculty was converted into an independent facility operating as a part of the Society of Scientific Courses - the Higher Gardening School, which in turn was later incorporated into the Gardening Faculty of the Warsaw University of Life Sciences after the country regained its independence. In the Austrian partition the first gardening courses were held in the 1890's at the Jagiellonian University's experimental garden. After the First World War in 1919 a Chair of Gardening was established at the Agricultural Study of the Jagiellonian University. Architects practicing garden planning, garden estates or areas of greenery also educated themselves at polytechnic schools abroad (in, among other places, Vienna, Berlin or Moscow), as well as in the country. The Technical Academy operated in Lviv (1844-1877) and was later converted into the Polytechnic School, where architecture was taught already during the nineteenth century. In Warsaw architecture was taught at the Warsaw University of Technology which was opened in 1915. In Krakow, architecture and mechanics, as sciences, were taught at the Krakow University already in the seventeenth century, being later taught at the Academy of Fine Arts and at the School of the Arts and Industry.

Works in the field of the history of garden design, in which their authors showcased the achievements of the modern planning of areas of greenery and presented problems from the disciplines of the history, theory and practice of historical landscape layouts, are also of significance [14]. These are primarily publications by garden design historians: Józef Drége (1904) [12], Kazimierz Buczkowski (1924) [2] and Edmund Jankowski (1923, 1938) $[22,23]$ as well as the architect and urban planner Tadeusz Tołwiński (1937) [44]. Gerard Ciołek who went on to become a historian of garden design and a tireless surveyor of Polish gardens, the founder of the Polish school of the renewal of historical garden layouts, but also a scholar of regionalism - of rural architecture and settlements, who placed matters of the protection and shaping of the landscape first, and a particularly distinguished person during the post-war period - was just beginning his professional career $[5,4]$. 
The leading designers of the turn of the nineteenth and the twentieth century and of the interwar period

Similarly, to the situation in other countries, the development of the new profession in Poland was closely tied with the landscape gardening boom of the eighteenth and nineteenth centuries. Both Polish and foreign gardeners were active here after 1772, with numerous guidebooks and handbooks on the establishment of gardens being published. Those that became famous included, among others, the architect Szymon Bogumił Zug (1733-1809), whose description of the gardens of Warsaw and its surroundings was included by C.C.L. Hirschfeld in his work [53, 19], Dionizy Mikler (D. McClair, 1762-1853) from Ireland, who was invited to Poland by Izabela Czartoryska, the author of the acclaimed book on English gardening entitled Myśli różne o sposobie zakładania ogrodów (Various thoughts on the manner of establishing gardens in English, 1805) [10], or Augustyn Denizot (1836-1910) from Switzerland, who was active in Greater Poland during a later period.

The leading garden designers of the start of the twentieth century were gardeners and garden planners by education: Teodor Chrząński (1854-1932), Walerian Kronenberg (1859-1934), Franciszek Szanior (1853-1945), Stefan Celichowski (18741961), Leon Danielewicz (1878-1970), Stanisław Schönfeld (1882-after 1938), Stefan Rogowicz (1885-1934), Edmund Jankowski (1849-1938) and Edward Ciszkiewicz. They were very often educated abroad or practiced there [7, 31]. Kronenberg, Jankowski, Chrząński and Szanior studied in France, while Tański - in Belgium and Germany. The biographies of these planners are quite varied and point to the knowledge and experience that they had gained. For instance, Walerian Kronenberg practiced at the nursery of Ch./ Ulrich and at Warsaw's Pomological Garden, afterwards working at the nurseries of Ludwig Späth at Neu-Britz near Berlin (1878-79), followed by working for Franz and Nicolaus Siesmayer in Bockenheim near Frankfurt. He gained a solid foundation of planning experience while working for Franz Heinrigh Siesmayer, the continuator of the work of Peter Joseph Lenné, gaining botanical knowledge from his brother, Nicolaus. During his practical training while working for the Siesmayers he established gardens under the supervision of the experienced gardener Sennholz, including such works like Rotschild's garden in Frankfurt. After finishing his practical training, he studied at the Higher Gardening School at Versailles. Kronenberg also travelled a lot, visiting well-known gardening nurseries. Another planner, Franciszek Szanior, praciced at the Warsaw pomological and botanical gardens, after which he passed an exam to be certified as a gardener, while in 1874 he graduated

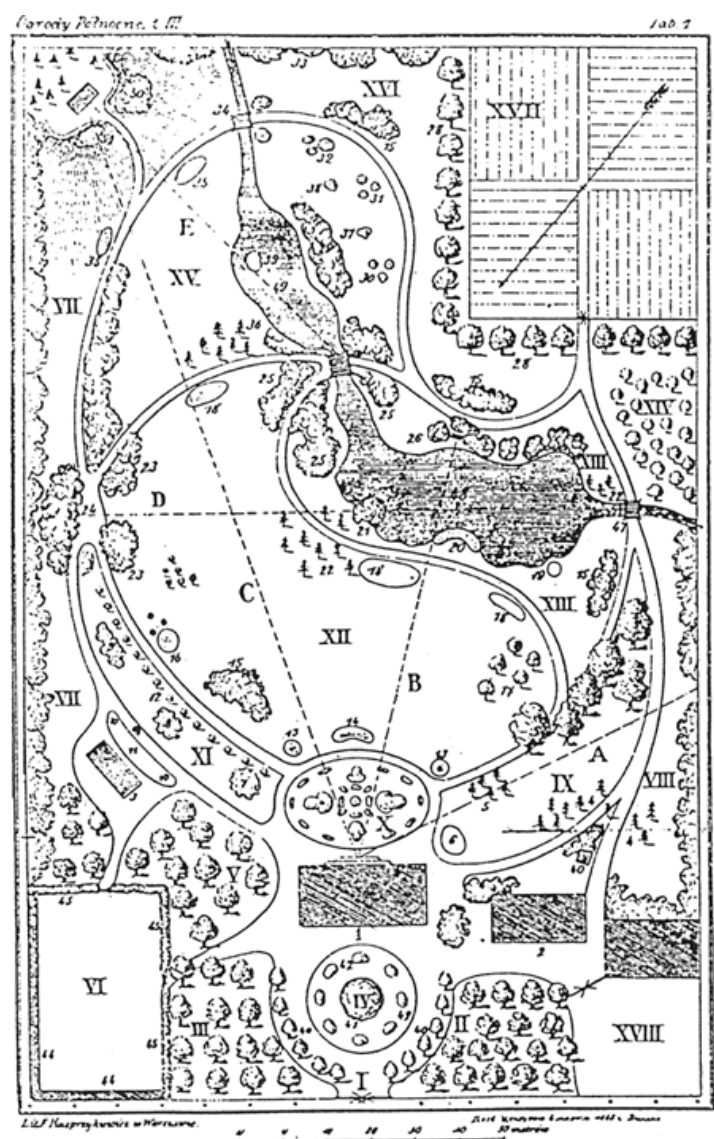

Fig. 1. Plan of the landscape garden.

Source: J. Strumitto, Ogrody pótnocne, ed. W. Tyniecki 1883.

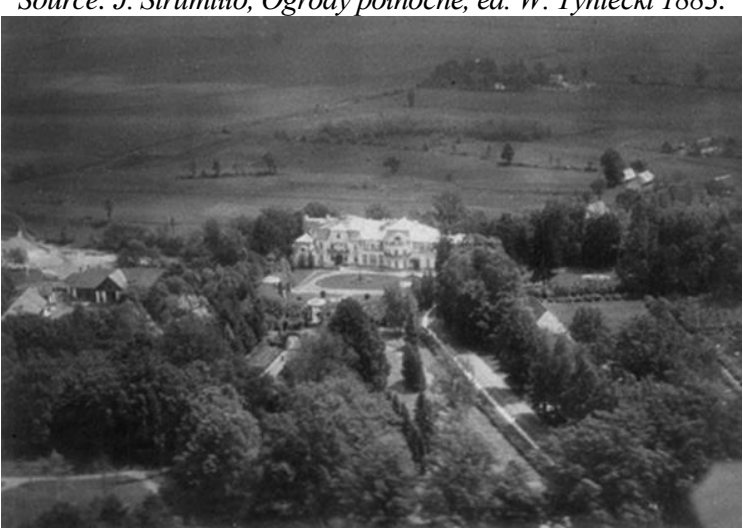

Fig. 2. Siary, palace garden, 1935, attributed to A. Röhring. Source: archives of A. Zachariasz.

from the l'École théorique et pratique d'arboriculture de la ville de Paris, which was founded in 1867 by the prefect Haussmann. Edmund Jankowski also graduated from this school. Stefan Celichowski underwent practical training at the Hoser Brothers' Facility in Warsaw, graduating from the Pomological Institute in Silesia and practicing in Dresden, Erfurt, Vienna and Paris. Some of the designs from the beginning of the twentieth century were still influenced by nineteenth-century historicism, "ornamental horticulture", the calligraphic style, as Janusz Bogdanowski called it [1], with engineer-like layouts and carpet flower beds drawn using draughtsmanship tools. We can see clear influence of 
E. Andre, J. Alphand, J.P. Barillet-Deschamps, as well as the grandeur of P. J. Lenne in the work of this first group of planners. However, modern, architectural forms developed over time - with a greater layout regularity and functionalism - as well as plant-based ones - e.g. the fashionable perennial beds. Those who have particularly significantly contributed to the development of modernist garden design and landscape architecture were active later: Franciszek Krzywda-Polkowski (1881-1949), Romuald Gutt (1888-1974), Zygmunt Hellwig (18991958), Alina Scholtz (1908-1996), Alfons Zielonko (1907-1999), Władysław Niemirski (1914-2001) $[5,7,21,35]$ and Władysław Czarnecki (1895-1983) $[8,9]$. In the group of modernists, Anglo-Saxon landscape architecture was a significant influence, which is evident in the experience of the designers and their completed projects. Krzywda-Polkowski was on a scholarship in England and practiced in the United States, while Hellwig practiced in England and also resided in the United States. Scholtz was on an internship in England. Their designs, competition entrees and publications are proof of the dynamic development of garden planning. They also show the coalescence of the profession and how views collided - views that were sometimes closer to gardening, while at others to architecture. From among the abovementioned designers, Polkowski, Gutt, Niemirski and Czarnecki obtained an architectural education, which is clear in the layouts that they designed, as well as in the composition and form, the designs of architecture and its surroundings, parks, cemeteries and conceptual urban designs. The remaining ones were gardeners who had their own garden and green areas design studios, as well as plant nurseries (including S. Rogowicz, W. Tański, S. Schönfeld, F. Szanior, Z. Hellwig, S. Celichowski) and thus imposed certain patterns and introduced fashions for specific plant material, while also usually participating in the training of new staff.

Another aspect of landscape architecture associated with the conservation of historical sites appeared already prior to the First World War due to the establishment of public or state organisations. In the Austrian partition in 1888 there emerged the Western Galicia Conservators Group, while in 1906 the Russian partition saw the establishment of the Society for the Care of the Monuments of the Past. The oldest institutions that had the character of government administration existed in the Prussian State, where a conservation office has existed since 1843 [32, 49]. Research work aiding in the conservation of historical sites - sometimes associated with the conservation of gardens - started already before the First World War. During the interwar period there was further development in research directed at saving destroyed gardens. This was naturally linked with the general need to rebuild the country and safeguard the reclaimed national heritage. This is why sites that were public property and that could fulfil representative functions were preferred, such as the surroundings of the Royal Castle on Wawel Hill in Krakow, as well as the garden terraces of the Royal Castle in Warsaw, the Royal Baths, the Saxon Garden, the garden in Natolin, the park in Białystok. At the Faculty of Architecture of the Warsaw University of Technology, Professor Oskar Sosnowski (1880-1939) organised systematic efforts that focused on gardens at the Polish Architecture Division, while in the years 1937-1939 Gerard Ciołek (1909-1966) along with Krystyna Żelechowska, supervised the Historical Parks Study [32, 51]. These were the beginnings of modern surveying, archival queries, studies and designs in this field. The nascent Polish school of studying and saving historical gardens would be confronted with the massive scale of wartime destruction after 1945. In addition, the sites that survived were under threat from secondary devastation resulting from far-reaching property changes introduced by the new political system in Poland.

\section{Professional titles used by representatives of the new profession in Poland}

Conflicts concerning the name of the profession resulted not only from the need of the nascent profession itself, but also from the discussions that were then taking place between architects and gardeners due to the changes that were taking place in the very subject of the designs - the garden itself - as well as the expansion of the scope of the work that needed to be featured in designs. In Poland the problem of naming, the scope of education and professional skills was often discussed in professional journals. E. Jankowski wrote in 1911: "In the previous issue we discussed ornamental gardening, often mentioning garden artists, garden designers. They are called here, in short, planners, while detractors claim that there are many stain makers among them (transl. note: a play on words was used in the original, in the Polish language: plamista - a person that causes stains to appear, is similar to planista - a planner). They claim the overall number of these planners to be over a hundred. There is no organisation, nor any agreement between them, however, they could form a serious professional association" [24]. Later on he criticised the inappropriate preparation of many designers as he believed that "Such work, performed in a reckless and unskilled manner, leaves behind a permanent trace in the form of an ornamental garden or park, which lasts several decades and sometimes even centuries" [24]. However, garden designers used many names for their profession and thus Jankowski, among others, used the term "gardener-naturalist"[33], Kronenberg used "gardener-landscapist", Rogowicz "gardener-architect", Tański employed the term 
"garden planner" and "gardener-landscapist" [48], while Alfons Zielonko - "gardener-architect" [52]. The problem of naming was a result of the philosophy of design and the type of education of each of the specialists, which was in the field of gardening in the case of the examples above, while also stemming from their professional activity and continental European education.

The problem of naming and the scope of professional work remained a matter of discussion over twenty years later. The subject was discussed, with perfect knowledge, by Zygmunt Hellwig in his article "Zawód bez nazwy i definicji" [18] ("A profession without name and definition" in English) "Horticulturalist-landscapist, horticulturalist-architect, architect of greenery, garden draughtsman, architect of the landscape, planner, horticultural architect, landscape architect. All these names, both individually and in various combinations, are used around the world in order to describe the artisttechnician who shapes areas covered by the economic activity of man. Who designs and construes certain elements of the current cultural landscape, such as gardens, parks, sports and recreational grounds [18]" Z. Hellwig wrote in 1934 of a new discipline landscape architecture", "for 30 years the profession of landscape architecture has had an outstanding and well-founded position in the United States /../. It owes this to two "dynasties" /../ of great artists, writers and pioneers - the dynasties of the Eliots and Olmsteds [18]". He discussed the nomenclature of the new profession in England and Germany in detail. Further, he noted "In Poland, unfortunately, all of the titles listed in the introduction have been used. The official name of the "Planners' Circle" professional association, which still exists (in a lethargic state), does not communicate much, as nearly all of its members use the title architect-gardener in their professional practice (an irrational translation of Garten-Architekt), or something similar. We can choose from three more or less identical rational and justified terms: planner, garden architect (or of gardens) and landscape architect. The first name already has a historical reason to exist in our country... Besides it reflects the modern broad professional competence of land and regional planning quite well. The second and third name are good, logical translations of appropriate titles from English and German". He asks "Does the profession of the landscape architect in the modern understanding of the term has a future in Poland?" and answered that at the time it had appeared that it did not. He assumed, however, that soon "the perspective of the future for this new profession will fundamentally change. The matters of the construction of park systems, planting roads and railways, streets, boulevards and sports grounds, river and marine waterfronts, the conservation of
National parks and making them accessible, cannot be solved and decided upon without causing damage by anybody but a competent landscape architect specialist who loves his profession" [18]. $\mathrm{He}$ believed that landscape architects should cooperate with gardeners and urbanists and work in regional offices, city regulation offices and gardening departments $[17,18]$.

\section{Major trends of the end of the nineteenth century and the first half of the twentieth century in Poland}

The end of the nineteenth and the first half of the twentieth century was a period when stylistic changes in gardens occurred faster than ever. Gardens were increasingly often being designed by professionally prepared specialists. The eclectic styles of the beginning of the twentieth century were being replaced by new forms - modernist ones, with architects who treated the garden as an extension of the home leaving a strong mark on garden design. Significant influence on the shaping of gardens was also exerted by the developing horticulture of newly introduced plants, supported by experiments in their acclimatisation. New strains were being developed, adapted to local conditions. Garden designs, including their modern perception and various functional and stylistic analyses became the domain of the dynamically developing discipline that was landscape architecture.

Transformations in the arts were important to the modern movement both in Europe and in Poland, starting from Arts and Crafts, through the Secession, De Stijl and art déco. Technical capabilities arrived later, along with the modern aesthetic of the Age of the Machine with its refreshingly innovative and elegant geometry of the international style. During this time there was a constant conflict in the field of gardens between three basic movements: naturalist, eclectic and modernist, which often blended with each other. However, in modernism, due to the pursuit of new forms of artistic expression, the transformation of the form of the garden was particularly visible [50]. Modernist solutions were characterised by simplicity and functionalism, while new forms found their expression in strong architecturalisation, modern materials and various forms of flower beds - either strongly geometricised or biomorphic. Changes that were taking place in architecture also had a significant effect. Garden and park design was seen as one of the tools of democracy in social transformations. This thesis had a fundamental impact on the development of modernism.

Landscape architecture, integrally linked with garden design, as any form of creative work, takes on current fashions and tendencies in the arts. Garden design has always been a reflection of a country's culture and the standard of living and tastes of its 
citizens. The garden historian, horticulturalist and garden planner, the author of several dozen books, Edmund Jankowski, ascribes an important role to gardens. He highlighted this in 1911 on the pages of "Ogrodnik": "What matters is not only the decoration of a given home, but also a certain mark of civilisation that parks make on a country. The more beautiful they are, the more ornament there is in the surroundings, the more exceptionally do they bear the signs of a nation's culture. Creating a beautiful ornamental garden was difficult in the past as well. Today, when requirements have increased, when an entirely new style is being born, in which plant units and groups become the supplementation of architectural ideas, when artistic and colourful wholes are created out of buildings and plants, when plant, tree and flower material has increased in a unique manner, it is not easy to be a good planner today" [24]. The beginning of the century was a period when styles and fashions changed rapidly in garden design, as they did in the arts in general, which affected the gardens being built. In 1937 Jankowski showed the transformations that "The modern style, which formed a couple of decades ago and has still not sufficiently matured into clear forms, has been taken by architects. They do not, in principle, consider gardeners as capable of planting gardens near houses themselves, acting on the assumption that a garden is only a necessary supplementation and extension of a home, that it must be adapted to it not only in style, but in dimensions of both space and the trees planted there as well [25]". Meanwhile the architect Antoni Porczyński, on the pages of "Ogrodnik", wrote "Gardening and architecture - they are sisters by birth, mutually supporting themselves and increasing their beauty - they are necessary to each other" [38]. Changes dictated by modern art were taking place increasingly fast. They entered Poland and were adapted to garden designs as well: "Stone, iron, lush greenery and colourful flowers, these are the fundamental elements of modern architectural gardens [39]". Publications show that gardeners and architects had conflicting views.

\section{Garden fairs}

Garden fairs, which were often organised at the time, typically featured a garden planning section, where designers presented their designs, were awarded medals, gained popularity and commissions. Directors of municipal plantations and municipal gardeners also presented their designs. The exhibitions presented new tendencies in garden design, they were discussed in the press and sometimes had their own publications [46, 37]. The "Exhibition of architecture and interiors in garden surroundings" of 1912 in Krakow was a significant event, organised on post-military grounds of the Krakow Fortress near Błonia and Park Jordana, and whose practical goal was to showcase typical houses against the background of the contemporary state of urban planning, that were described as "both practical and beautiful to residents of both town and country, and thus a type of a suburban manor house, small houses for a worker or craftsman, a farmhouse" [46]. The houses were presented in garden surroundings. The Krakow fair was visited by Ebenezer Howard in connection with the Eighth World Esperantist Congress. He delivered a lecture at the fair on the 14th of July 1912, and, as it was written, "Admired quite uncritically the wonderful layout of Krakow with its great amount of greenery, greens, plantations, a ring plan system, etc. and called Krakow a naturally developed garden-city [34]".

The Anniversary Horticultural Fair in Poznan that took place between the 25th of September and the 3rd of October 1926 became famous and was visited by around 185 thousand people [36]. It was decided that it was at a truly European level. It provided an image of the condition of garden design from all over Poland, gathering numerous exhibitors. The site of the fair, the International Poznań Fair Grounds, which existed from 1921 (although they had older partition-era traditions, as in 1911 the Eastern German Fair was held here). The fair of 1926 had a substantial publication and promoted the achievements of cities and towns. Franciszek Szanior, when commenting on the achievements of Polish planning, wrote: "Anyway, it should be highlighted that our larger cities are moving ever forward in terms of establishing new parks, green squares, sports pitches and overall in terms of structuring and decorating their plantations [43]". He later added: "Finishing the comments addressed at the Poznań Fair, I express my concern for this beautiful branch of gardening ornamentation that is the planning of parks and the establishment of ornamental gardens not to disappear in our country completely. It is the duty of young specialists to uphold this beautiful art and to make efforts so that young Poland can bloom anew with a love of the beauty of gardens and maintain its past traditions in this direction [43]".

Between the 28th of July and the 4th of October 1928 a fair was held in Torun which, through showcasing examples of completed projects, was meant to shape modern taste. When reporting on this event, Marian Guntzel described the changes that took place in post-war art and the emergence of modern movements: futurism, expressionism and cubism. He wrote that gardening was subjected to them as well. He presented two designs that were exhibited by the city of Bydgoszcz which showed the state of modern garden planning in the west, which he described as such: "The distinct characteristic of the post-war period is the desire to use and the constant pursuit of changing sensations /.../ The art of construction or architecture, as a visual art, has transformed most significantly during the post-war period, 


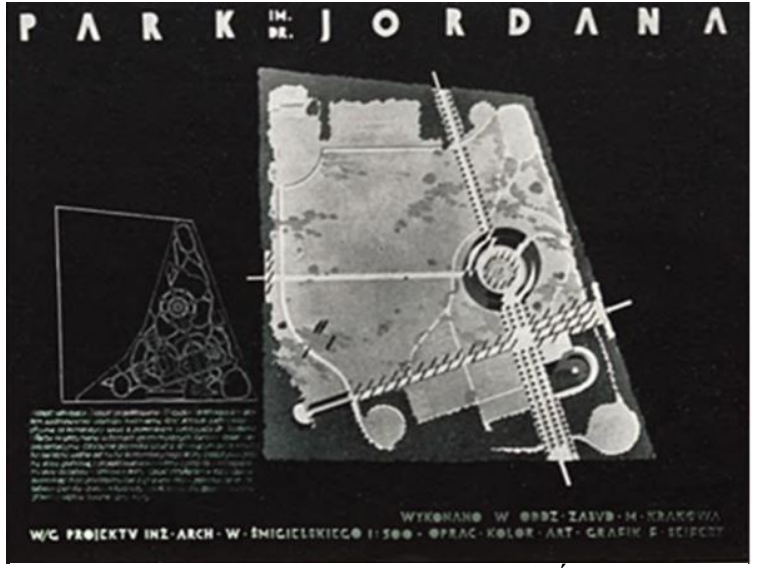

Fig. 3. Design of Park Jordana in Krakow, W. Śmigielski, 1935. Source: W. Śmigielski, Funkcjonalizm nowoczesnego parku, "Dom Osiedle Mieszkanie", December 12 1935, p. 33.

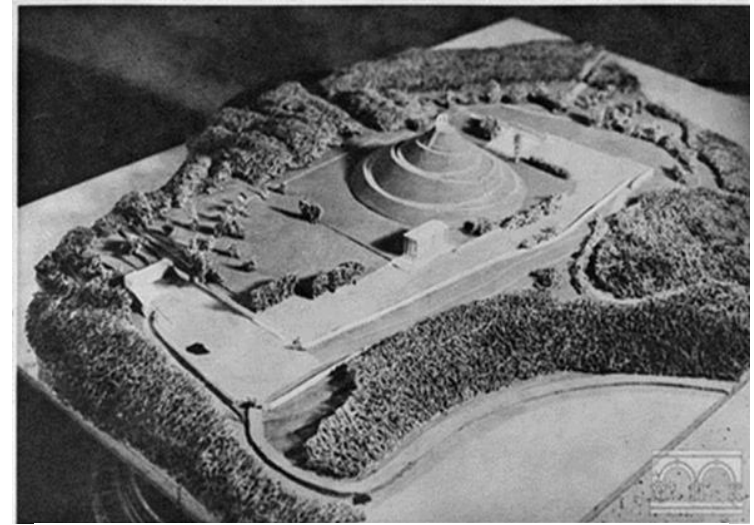

Fig. 4. The surroundings of the Pitsudski Mound in Krakow, according to a design by R. Gutt and A. Scholtz, which received first prize in a competition organised in $1936 \mathrm{~b} /$ mock up, 1937, MHK-4950/N.

with garden architecture closely following it. The modern villa garden is an extension of the building, which means that it is organically connected with a dwelling and stylishly adapted to a building's architecture /../ Efforts are constantly made to highlight the perpendicular line everywhere, contrary to past methods, in which the horizontal line and plane were dominant [15]".

In 1935, at the III Congress of Gardeners in Poznań, an exhibition of Municipal Greenery was presented, organised under the direction of Władysław Marciniec, while Stanisław Schönfeld presented the condition of greenery in Polish cities, which, as he believed, left much to be desired, which was in part the result of low budgets [16].

\section{Achievements in the design of greenery in cities}

The traditions of taking care of greenery and the public space of the city can be seen in the activity of the Commissions for Good Order. The first Commissions of Good Order (boni ordinis) - collegial institutions of municipal administration, were established in 1764 as a result of the decision of the Convocational Sejm. In 1765 king Stanisław
Poniatowski established such a commission for Warsaw, while in 1768 the Sejm decided to establish them for all royal cities. The commissions oversaw, among others, municipal finances and issued ordnances for individual cities, making spatial planning decisions. Thanks to their activity many cities saw the planting of trees along streets, the establishment of parks and greens while care for the surroundings of cities, including Krakow, Poznań, Lublin and Kalisz, increased. The first parks for use by the wider public in Poland were made accessible by aristocrats. The Saxon Garden was opened in Warsaw in 1727, while the garden of the Krasiński family (1768) and the Royal Baths were opened later. From the end of the eighteenth century and over the course of the nineteenth centuries cities included socalled pleasure gardens (German Volkspark). In partition-era Poland there were public parks being built in, among other places, Kalisz (1798), with the Saxon Garden being built in Lublin (1837), while Krakow saw the establishment of "plantations" that surrounded the city with a green ring in place of tits dismantled fortifications, as well as Marksmen's Park (1837). This later became a wide-reaching phenomenon that excellently fitted in with the park movement. Many excellent public parks and areas of greenery were established, often featuring an innovative programme. These were, among others, in Łódź: Poniatowski Park (T. Chrząński, 1904-1910), Piłsudski Park (E. Ciszkiewicz, the Zajkowski's, 1929), in Warsaw it was Skaryszewski Park (F. Szanior 1906-1915) [5], in Katowice - Kościuszko Park (expanded in 1926-31) [45], while in Krakow the Park of doctor Jordan (on the grounds of an agricultural and industrial fair, K. Zaremba, 1885, B. Malecki, 1887) - a park for children and the youth (a model for future gardens of this type in Poland), Bednarski Park (1896) on the grounds of a former quarry or the surroundings of the Piłsudski Mound (R. Gutt, A. Scholtz, 1936). The transformations in the form of the sites being designed could be clearly seen. Eclecticism and calligraphic layouts gave way to simple geometricised and modernist forms. A sports programme: pitches, playgrounds (often areas for the practicing of gymnastics, running or tennis), usually in the form of a rectangle, circle or hippodrome, became mandatory. In the group of the examples presented above, their designers were primarily gardeners and garden planners by education. The architects among them include Karol Zaremba, whose calligraphic design was developed by the gardener Bolesław Malecki, and Romuald Gutt (he studied at the Winterthur Technical School and at the School of the Fine Arts in Zurich in the years 19051908), who cooperated with the gardener Alina Scholtz numerous times, together creating advanced, modernist works, including the famous villa and garden in Warsaw, at Kielecka Street, or the design of 
a pavilion with a garden for the Paris exhibition in 1937, which was rejected by the competition jury.

After regaining independence in 1918, numerous efforts were made in Poland in order to rebuild its cities and the country [13,41]. Parks and areas of greenery were among the mandatory elements of the programme implemented by municipal authorities. Proposals were made to create systems of greenery and regional systems. The concept of Poznań's system of areas of urban greenery was important. The ringbased layout of urban open spaces by Joseph Stübben (1903), considered one of the first examples of modern urban planning, was developed by Władysław Czarnecki (1932) [8, 9]. He used green river wedges (the so-called Maltese cross), formed by naturally shaped river valleys: of the Warta, Bogdanka and Cybina rivers, which exit from the interior of the city in an east-west and north-south layout. Ebenezer Howard's concept of the garden-city was also well received. In Poland it was described in Tygodnik Polski (1899) in the article Miasto-Ogród by Wojciech Szukiewicz. In 1909 dr Władysław Dobrzyński founded the Delegation for matters of garden-cities at the Warsaw Hygienic Society. Dobrzyński, along with Howard, was the co-founder of the International Garden Cities and Town Planning Association and a member of its board of directors. Despite the fact that Howard had called Krakow a "naturally developed garden-city", it was not Krakow, but areas near Warsaw that became the site of the construction of garden-cities. Around a dozen settlements called garden-cities were built at the time, including Ząbki (T. Tołwiński, 1912), Miasto-Ogród Podkowa Leśna (A. Jawornicki, 1927). Earlier, this type of industrial housing estates was also being built in Silesia, e.g. Giszowiec (G. and E. Zillmann, 19061910) or Knurów - III Kolonia (K. Henrici, 19041910) [50]. Greenery - public parks, home gardens, avenues and the landscape co-created the genius loci of these complexes.

Comprehensive surveys of greenery in cities were performed, e.g. in Zakopane [42] and Katowice [45]. Comprehensive and modern analyses were undertaken, also covering participative actions, cf. e.g. Kwestionariusz lustracyjny do objazdów miast obrazujacy stan $i$ rozwój plantacji publicznych... (Inspection questionnaire for city review trips. The condition and development of public plantations in English) written by the Plantation Committee of the Cities of the Republic [30].

The Inspection questionnaire for city review trips. The condition and development of public plantations (1922) included 46 detailed questions, among which, part from basic statistical data and that concerning land use, also included:

- in the first, general part: 17. Institutions or circles particularly interested in the establishment and development of municipal plantations; /../
19. Local manifestations of interest in gardening: aesthetic efforts: a) by the magistrate; b) various institutions, c) residents; 20. The state of the propagation and popularisation of gardening and respect for plants, e.g. by schools, sporadic lectures, municipal holidays, tree plantings, posters, etc.; 21. Visible and confirmed beneficial influences on the development of gardens and municipal plantations, e.g. a) general interest of residents; b) the prosperity of the city and backing from the magistrate; c) particular influence of local activists; d) gardening societies; d) beneficial local placement; 22. Creative influence of wartime operations, e.g. military gardens and green squares, ornamental cemeteries, etc. /../ 27. Budget positions concerning the maintenance of gardens and plantations.

- in the second, special part: 34. Areas of tree stands and municipal plantations; 35. Type, age and current condition of public plantations: a) parks and gardens, b) green squares and riverside boulevards; c) forested areas and avenues, streets and roadways (dimensions, planting method); d) burial cemeteries; e) and located near churches; f) hospital and sanatorium gardens; g) school gardens; h) station plantations; i) and gardens near other public buildings; 36. Type, age and current condition of private gardens and home gardens in front of residential villas and suburban holiday homes; 37. Sports and game squares, pitches, stadiums, etc.; 38. Municipal tree nurseries and forests; 39. Private tree nurseries and forests; 40. Private gardening companies; 41. Desired current plantation general development; 42. Plantation care and maintenance procedure; 43. Places inside the city with a striking lack of plantations and that are suitable for this purpose, their size and type of desired ornamental elements; 44. Suburban sites well-suited for the establishment of public plantations and sports areas; their actual area and desired type of arrangement; 45. The types and species of trees, bushes and plants that stand out through their health and lush growth; 46. Species and types of plants that have been inappropriately selected in terms of local conditions [30].

Apart from plantations, municipal parks and cemeteries, gardens funded by industrial plants were also being built, e.g. the designs of gardens near mines, e.g. Saturn in in Czeladź, by Celichowski. Rest and recreation were appreciated, with folk pleasure parks being built, for instance for the Niwka factory settlement (Będzin powiat), which had a population of five thousand [40]. Stefan Rogowicz promoted the educational benefits of didactic gardens addressed to the youth, which could serve to educate and improve physical fitness. 
Many efforts were undertaken in order to improve the situation, e.g. the initiative of the Minister of Interior Affairs dr Felicjan Sławoj-Składkowski, who published Circulaire (2.11.1927): "I recommend that during the months of March and April 1927 the squares and streets of cities, towns and villages be planted with trees. /../ To this end, appropriate sums for this purpose should be included in the budgets of local governments and preparatory work should be performed during winter, such as: placing orders for young trees, fertilising earth, contracting specialists, etc. /../ It would also be desirable to create a "Tree Planting Commission" in each locality and for them to develop plans for approval by Starosts or Voivods. The guidelines for the work of the Commissions should be the planting of trees, bushes or flowers, or otherwise vines in every place where such is possible."

\section{The Master and his students - Franciszek Krzywda- Polkowski as well as Alina Scholtz and Gerard \\ Ciolek}

The architect Franciszek Krzywda-Polkowski (18811949) was one of the more important persons among the propagators of landscape architecture and garden planners. He graduated from Wawelberg and Rotwand's mechanical and technical school in Warsaw, afterwards completing studies in the visual arts at the School of Painting, Sculpture and Architecture in Moscow, which he had to constantly put on hold in order to earn small sums of money in Warsaw's architectural studios to cover the cost of his education. He completed his studies in Moscow in 1912. At the turn of 1913 and 1914 he was on a scholarship in England, and in the years 1924-25 he worked at the American design practice McKim, Mead \& White in New York [47]. During his stay he visited Boston, familiarised himself with the Arnold Arboretum [11], which constituted an element of the "Emerald Necklace" park system (designed by F. L. Olmsted senior and Ch. Eliot). He observed the development of landscape gardening in its various forms, the currents of modernism and naturalism, as well as the sheer scope of landscape architecture, which provided him with knowledge in this field. Krzywda-Polkowski was the first to introduce the landscape architecture specialisation to university-level education. From 1928 onwards, he organised and directed the Landscape Architecture and Park Studies Division at the University of Life Sciences in Warsaw. He also worked at the Academy of Fine Arts in Krakow. In 1932 he was given the post of profesor nadzwyczajn - equivalent to an associate professor, at the Chair of Interiors and the Landscape at the Faculty of Architecture of the Warsaw University of Technology, where he was named profesor zwyczajny of the Chair of Garden and Landscape Design (profesor nadzwyczajny is a professorial rank used in
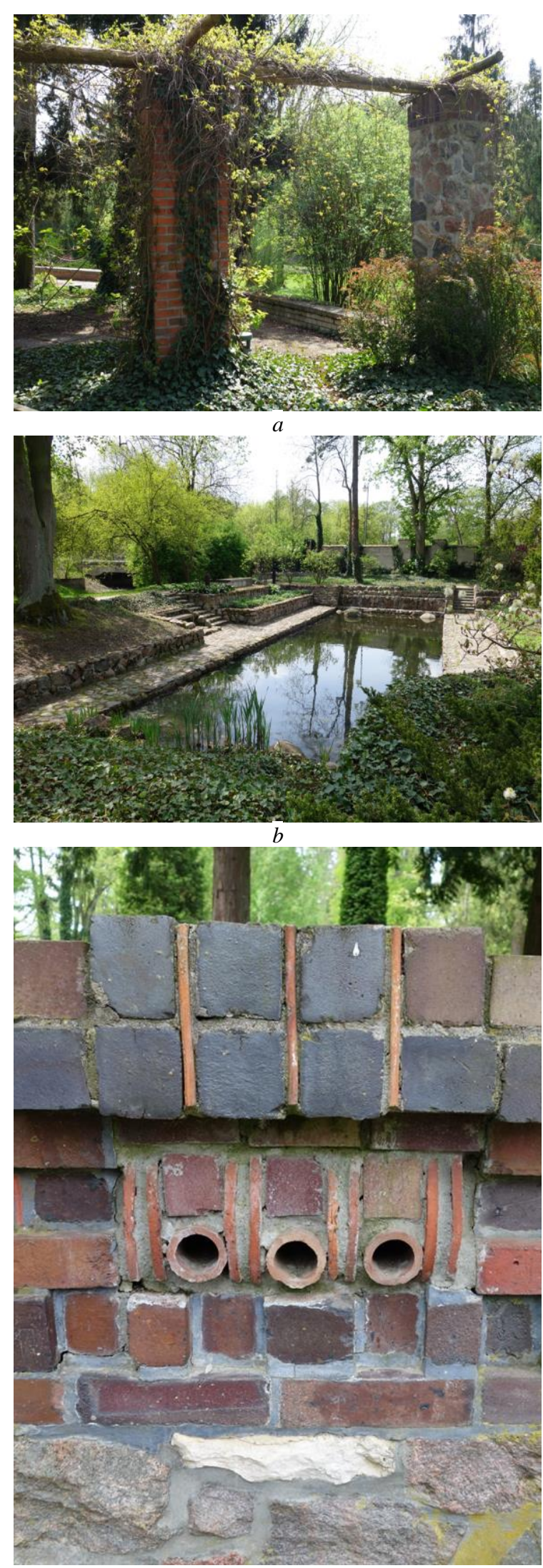

Fig. 5. Żelazowa Wola, design by F. Krzywda Polkowski, a) pergola; b) Czarny Staw (Black Pond); c) detail Photo by A. Zachariasz. 
Poland that is below that of profesor zwyczajny - full professor) [26, 47]. He influenced the education of garden planners, and among his diploma students there were, among others, Alina Scholtz [20] and Gerard Ciołek (at the Warsaw University of Technology) [4].

Alina Scholtz (1908-1996) was Polkowski's student and later assistant and co-designer. In 1932 she defended her diploma project entitled Design of a decorative park near the Royal Castle in Warsaw at the Landscape and Park Studies Division of the University of Life Sciences in Warsaw. Scholtz was a prolific designer, by 1939 she designed, among others, numerous private gardens and the Horseracing Track in Służewiec (the park surroundings) and Niebieskie Źródła Park in Tomaszów Mazowiecki. She also cooperated with the architect Romuald Gutt. The private home with a garden at Kielecka Street in Warsaw (1934) designed by this duo was awarded a silver medal at the Arts and Technology exhibition in Paris in 1937 [20]. They also won two competitions that were important to national identity - for the design of the surroundings of the Piłsudski family manor and park in Zułów (1935, built up to 1938), as well s the surroundings of Marshal Piłsudski Mound on Sowiniec Hill in Krakow (1937, construction halted by the outbreak of the war). She was very active after the war. She designed, among other projects, the areas of greenery near the W-Z Route, the design of the reconstruction and refurbishment of the Saxon Garden (with R. Gutt), the design of People's Park, numerous greenery designs for housing estates and the garden of the Embassy of the People's Republic of China. In 1948 she became a founding member of the International Federation of Landscape Architecture (IFLA) and was a delegate of the Polish Architects' Association to the IFLA for many years.

The most famous of Krzywda-Polkowski's completed garden projects is the park "in the memory of Chopin" in Żelazowa Wola. A. Scholtz cooperated with him on the design. A park-monument was built, surrounding a manorial complex - the place of Chopin's birth, with the programme featuring, among other elements, a mausoleum and a stage for music performances. The complex was designed in the current of preserving national heritage. Polkowski paid particular attention to creating an appropriate atmosphere. He fully used the possibilities provided by the slightly sloping terrain with the picturesquely regulated Utrata River. A unique modernist garden was established, designed while utilising knowledge of contemporary trends in landscape architecture. Polkowski programmatically departed from the thencurrent tradition of the rural landscape park. He designed diagonal layouts, perfectly using rhythm and asymmetry. He used pergolas, terraces, small masonry walls and pools of water with an architectural frame a rectangular pool in front of the entrance - in order to obtain a mirror-like effect, and the recessed Czarny pond. Loose shapes of greenery were superimposed on the rather regular layout. Plants from many Polish nurseries were used in the design, with most of them being donations. Several or perhaps even around a dozen thousand plants were collected, with the garden becoming an arboretum [11, 47]. Quite a lot of coniferous plants, cover plants, as well as perennial and rose plant beds were used, with cut forms used alongside colourful fields of naturalist plantings. The architectural details in Żelazowa Wola are unique, including gazebos, small stone walls, columns, pergolas, the fence, the stage, the bench with a sitting space, but primarily various types of paved surfaces. They feature excellent material solutions. The masterful combination of a multitude of materials that produced a harmonious effect of a coherent whole is truly amazing. Traditional craftsmanship and construction work is at its peak here. Many of the elements were built on-site. Polkowski used, among other things, thick field granite, fired sand and lime brick, clinker and cement [27]. The park furniture has contrasting colours, e.g. brick set against a white concrete floor surface in front of the manor, brick set against the grey of flushed concrete or the painted details of the gazebos and the stage for music performances (ultramarine-coloured grout). Polkowski also strived to give structures a picturesqueness through the tectonics of their massings and various material combinations that are visible on the curbs surrounding the paths, in the fence (built out of various materials that is very visually expressive thanks to the shadows cast by its complex shape) as well as in the massings of the gazebos [47].

These modernist park-monuments were highly praised by Gerard Ciołek. When reporting his stay at the Essen horticultural fair of 1938 he regretted that Żelazowa Wola, Sowiniec and Zułów had not been exhibited there, stating that they "would have undoubtedly been hailed as outstanding against its background" [6].

Gerard Ciołek (1909-1966) - an architect and planner, historian and conservator - played an outstanding role in the protection and conservation of monuments of garden design, as well as of the cultural and natural landscape during the post-war period. He graduated from the Faculty of Architecture of the Warsaw University of Technology in 1936 on the basis of his diploma project: Design of a park of cultural entertainment and recreation. He started working on surveying Polish gardens already before the war. Ciołek amassed an immense archive: hundreds of plans, copies, measurement annotations, excerpts and notes, photographs, etc. collected in the so-called Ciołek Files (with over 7000 entries, including around 2000 plans of historical parks and gardens). He started gathering materials during the 
war. After the Second World War he became the head of the Department of the Protection of the Landscape and the Home Lands at the General Directorate of Museums and the Protection of Historical Monuments. A campaign of the registering and documentation of garden layouts was set in motion thanks to him. The archive constituted an excellent research toolset for the investigation of historical garden layouts in Poland against the background of European art. The studies were crowned with his most famous work, Ogrody polskie (1954). Ciołek created the methodological foundations of the refurbishment and reconstruction of historical gardens - "The conservation of gardens is a novelty here and the work that is being done today is pioneering, both in terms of research and study methods, as well as in terms of actual work /../ In a historical garden, regardless of its style, the most important value is its composition, its intended spatial layout, within which the plant material constitutes but one of many elements that together form a harmonious, complete whole [3]". Ciołek was the author of refurbishment designs of around a hundred historical gardens, including, among others, Arkadia, Baranów, Jabłonna, Łańcut, Nieborów, Wilanów, Puławy, Rogalin. In the post-war period manorial and park gardens were, due to political changes, an uncomfortable subject. They were perceived as a symbol of predatory landownership and often left to be destroyed. Many of them did not survive, with only the charts in Ciołek's File recording their fleeting beauty.

Ciołek was assigned to Krakow in 1948 as a deputy to a professor at the Faculty of Architecture of the Polytechnic Faculties of the AGH University of Technology, from which the Cracow University of Technology and its Faculty of Architecture separated themselves in 1946. In 1954 he was appointed profesor nadzwyczajny and the director of the Chair of Spatial Planning of the Cracow University of Technology, and after the reorganisation of the chairs and divisions he took the post of the newly established Chair of the Planning of the Landscape and Green Areas. Professor Janusz Bogdanowski was one of his students.

\section{The problem of education and the scope of the work of landscape architects in Poland}

The problem of the education of landscape architects was mentioned several times in pre-war publications, in addition to publications on the subject. Teaching garden design and the broadly understood gardening department were also treated with much care. Edmund Jankowski had particular contributions in the latter. The problem became more prominent after Poland regained its independence. Z. Hellwig and F. Krzywda-Polkowski [37, 17, 28] expressed their views on the matter of landscape architects.
F. Krzywda-Polkowski was the first to introduce landscape architecture into university-level education at the University of Life Sciences in Warsaw. During the 1930/1931 academic year the Gardening Faculty Council of the University of Life Sciences commissioned F. Krzywda-Polkowski, a professor of architecture, to establish a Division. Previously, during the 1929/1930 academic year, the Faculty of Gardening formed a specialisation in the arrangement of parks and gardens, whose beginnings were the lectures and classes on park studies as a part of mandatory practical classes for students during the 1928/1929 academic year. The legal basis for the establishment of the specialisation was the ordinance of the Minister of Religious Denominations and Public Enlightenment of the 26.IX.1923 § 5, which called for there to be two primary study courses at the Faculty of Gardening of the University of Life Sciences: a utilitarian and decorative one. The classes of the decorative course included: detailed park studies, establishing and maintaining ornamental gardens, urban horticulture, garden architecture, plan draughtsmanship with perspective drawing and painting. During the $1935 / 1936$ academic year the landscape architecture specialisation found a building for itself in Warsaw at Rakowiecka Street. Up to 1939 its lecturers were: professor Krzywda-PolkowskiDivision director, R. Gutt, R. Adwentowicz, K. Tomorowicz and A. Scholtz, one of the first female graduates of this specialisation [20]. As we can see, the specialisation developed quite well up to the Second World War.

There was also observable activity in the community to improve the then-current state of knowledge on landscape architecture. Addressing the gaps in the education of municipal gardeners and assuming that the matter of plantations was not duly appreciated and poorly handled, attempts were made to change this by running supplementary education courses. The Society of Polish Urban Planners organised the "First supplementary education course for municipal gardeners" in 1935. Its curriculum shows that outstanding designers and practitioners who cared about the beauty of greenery in the city were involved, expressing this care through improving the qualifications of municipal gardeners [29].

\section{Conclusions}

A brief and incomplete overview of the beginnings of landscape architecture in Poland has been presented here, as well as a review of works across all scales - from planning to architectural detail. It was a time when landscape architecture built up and reinforced its position among the design arts. The designers who represented it were finding their place between architecture and urban planning and the main subjects of their designs were parks, gardens and 
various types of areas of greenery, the external surroundings of buildings and areas of rest and recreation. It is clear that landscape architecture is one of the most diverse and multi-threaded disciplines, in which two strong and equally important currents exist: the natural and cultural one. The search for the name of the profession and the design experiences of practitioners coming from different specialisations confirm the complexity of the profession and show its interdisciplinary character.

Landscape architecture developed along with new design tendencies, technologies, new plant strains and species, new construction materials. Works of interwar-period architecture in Poland represent a high level of artistry, innovative solutions and perfect craftsmanship. There is a group of designs in which national identity became particularly important, building symbols through forms and the relations between architecture, urban design and plant material. It was believed that graduates educated in landscape architecture, upon finishing their studies, would be able to "put an end to the further dominance of ugliness and senselessness in our civilisational system [18]".

\section{References}

1. Bogdanowski, J. Polskie ogrody ozdobne. Historia i problemy rewaloryzacji. Warszawa: Arkady, 2000.

2. Buczkowski, K. Z ogrodów stylowych w Polsce. Kraków: Gebethner i Wolff, 1924.

3. Chrabelski, K. Ciołek, G. Uwagi o potrzebie i metodzie odbudowy zabytkowych ogrodów. Ochrona Zabytków, 1949, iss. 1, p. 15-19.

4. Ciołek G. (1909-1966), biography, http://www.ciolek.com/people/ciolek-ga.html, retrieved on 06.2017.

5. Ciolek, G. Ogrody polskie. Warszawa: Architektura i Budownictwo, 1954.

6. Ciolek, G. Pod arkadami. Arkady, 1935, 05, p. 229.

7. Ciolek, G., Plapis, W. Materialy do stownika twórców ogrodów polskich, Warszawa: PWN, 1968.

8. Czarnecki, W. Planowanie miast i osiedli, t. III. Krajobraz i tereny zielone, Warszawa: PWN, 1968.

9. Czarnecki, W. To byt też mój Poznań. Wspomnienia. Poznań: Wyd. Poznańskie, 1987.

10. Czartoryska, I. Myśli różne o spsobie zakładania ogrodów, Wrocław: W. B. Korn, 1805.

11. Dolatowski, J. Dudek-Klimiuk, J. Notatki o zasobach roślinnych i historii parku w Żelazowej Woli. Rocznik Polskiego Towarzystwa Dendrologicznego, vol. 63, 2015, p. 59-68.

12. Drége, J. Ogrody w Polsce, In: Wielka Encyklopedia Powszechna Ilustrowana, series 2, vol. 4, Warszawa: S. Sikorski, 1904, p. 906-957.

13. Drexler, I. Odbudowanie wsi i miast na ziemi naszej, Lviv: Zakład Narodowy im. Ossolińskich, 1921.

14. Grochowski, T. Zarys bibliografii ogrodniczej polskiej, Kraków: Tow. Ogrodnicze, 1927.

15. Guntzel, M. Nowoczesne ogrody architektoniczne na wystawie ogrodniczej w Toruniu. Ogrodnik, 1928, iss. 18, p. 345-347.

16. Hellwig, Z. III Zjazd Ogrodników Miejskich w Poznaniu. Przegląd Ogrodniczy, 1935, iss. 11-12, p. 334-337.

17. Hellwig, Z. Ogrodnik - rękodzielnik, architekt, czy ktoś trzeci. Przegląd Ogrodniczy, 1935, iss. 11, p. 340-344.

18. Hellwig, Z. Zawód bez nazwy i definicji. Przeglad Ogrodniczy, 1934, iss. 11-12, p. 332-356.

19. Hirschfeld, C.C.L. Theorie der Gartenkunst, vol. 1-5, Leipzig: Weidmann, 1779-85, vol.5, p. 293-313.

20. Information available at the Chair of Landscape Architecture of the University of Life Sciences in Warsaw (SGGW), http://kak.sggw.pl/pl/historia, retrieved on 05.2017

21. Jankowska, M. Warszawskie środowisko ogrodników-planistów na przełomie XIX $i$ XX w. Warunki ksztaltowania się zawodu. In: Architektura i urbanistyka w krajobrazie historycznym Królestwa Polskiego 1815-1914. Warszawa: Stowarzyszenie Konserwatorów Zabytków, 1992, p. 116-122.

22. Jankowski, E. Dzieje ogrodnictwa w Polsce w zarysie, Warszawa: Druk. K. Kopytowski i S-Ka, 1923, p. 209-210.

23. Jankowski, E. Dzieje ogrodnictwa, vol.1-2, Kraków: Polska Akademia Umiejętności 1938.

24. Jankowski, E. Rzut oka na nasze ogrodnictwo. Ogrodnik, 1911, iss. 16, p. 275-276.

25. Jankowski, E. Sztuka i ogrodnictwo. Ogrodnik, 1928, Y. XVIII, iss. 3, p. 43.

26. Krzywda-Polkowski, F. In: Polski Stownik Biograficzny, vol. XXVII/2, b. 113, Wrocław: Wyd. PAN, 1982, p. $320-322$.

27. Krzywda-Polkowski, F. Park w Żelazowej Woli, Chopin. 1937, b. 1, p. 15-24.

28. Krzywda-Polkowski, F. „Krajobraz, architektura i ogrodnictwo” w zagadnieniach miejskich, Przeglad Ogrodniczy, 1935 , iss. 11 , p. 337-340.

29. Kurs dokształcający dla ogrodników miejskich. Ogrodnictwo, 1929, iss. 1, p. 26-27.

30. Kwestionariusz lustracyjny do objazdów miast. Stan i rozwój plantacji publicznych w świetle zebranych materiałów, materials collected by F. Szanior and W. Zajkowski, Warszawa 1922.

31. Loza, S. Architekci i budowniczowie w Polsce, Warszawa: Budownictwo i Architektura 1954

32. Majdecki, L. Ochrona i konserwacja zabytkowych założeń ogrodowych, Warszawa: PWN 1993, p. 92-94.

33. Majdecki, L. Twórczość planisty Stefana Celichowskiego. Warszawa: PWN, 1969, p. 28-29.

34. Miasta-ogrody, Architekt, Y. XIII, 1912, iss. 8, p. 82.

35. Polscy architekci krajobrazu przełomu XIX i XX wieku. Niemirski, A., Szumański, M. (eds). Warszawa: Wyd. SGGW, 1996.

36. Ostrowski, E. Jubileuszowa Wystawa Ogrodnicza w Poznaniu. Ogrodnik, 1926, iss.19, p. 364.

37. Pamiętnik jubileuszowy wystawy ogrodniczej w Poznaniu. 25.IX-3.X.1926, Poznań: Komitet Jubileuszowej Wystawy Ogrodniczej, 1926.

38. Porczyński A. Architektura a ogrodnictwo. Ogrodnik, 1911, iss. 3, p. 74.

39. Rogowicz, S. Ogrodnictwo dekoracyjne w świetle Międzynarodowej Wystawy Sztuki Dekoracyjnej w Paryżu. Ogrodnik, 1925, iss. 14, p. 384. 
40. Rumun, H. Ludowe parki zabaw i gier, Przeglad Ogrodniczy, 1928, iss. 5, p. 142-145.

41. Rybka, A. Centralny Okręg Przemystowy a polska awangardowa urbanistyka międzywojenna, Rzeszów: Oficyna Wydawnicza Politechniki Rzeszowskiej, 1995.

42. Stecki, Dr., Korczyńska. Wykaz drzew rosnących na terenach projektowanych zieleńców publicznych m. Zakopanego - inwentaryzacja. Uwagi do stanu i doboru gatunków, 1940; Archiwum Narodowe, Oddz. Nowy Targ, AmZ 219, unpublished.

43. Szanior, F. Z Wystawy Jubileuszowej Ogrodniczej w Poznaniu. Przeglad Ogrodniczy, 1926, iss.10, p. 341-342.

44. Tołwiński, T. Budowa miasta współczesnego, Warszawa: Zakład Urbanistyki Politechniki Warszawskiej, 1937.

45. Vergin, E. Grünflächenpolitik der Stadt Kattowitz, Poln. Oberslesien. Gartenkunst, 1932, iss. 45, p. 54-57.

46. Wystawa architektury $i$ wnętrz w otoczeniu ogrodowem w Krakowie, Kraków: Druk. Uniw. Jagiellońskiego 1912.

47. Zachariasz, A. Architekt Franciszek Krzywda-Polkowski a początki architektury krajobrazu w Polsce, na tle zmian zachodzacych w Stanach Zjednoczonych i Anglii, In: Studia nad architekturą i urbanistyką polski międzywojennej Tom III. Architektura, krajobraz i ludzie, Kraków: Wyd. Politechniki Krakowskiej, 2017, p. 7-41.

48. Zachariasz, A. Early development of the profession of landscape architect, In: III Forum of Landscape ArchitectureNew ideas and development in landscape architecture in Poland, ed. P. Wolski, Warszawa: Ośrodek Ochrony Zabytkowego Krajobrazu, 2000, p. 324-333.

49. Zachariasz, A. O zabytkowych ogrodach. O konserwacji $i$ restauracji żyjacych dzieł sztuki. In: Przeszłość dla przyszłości, vol. 4, Kraków: Wyd. Politechniki Krakowskiej, 2015, p. 117-136.

50. Zachariasz, A. Zieleń jako współczesny czynnik miastotwórczy ze szczególnym uwzględnieniem roli parków publicznych, Kraków: Wyd. Politechniki Krakowskiej, 2006.

51. Żelechowska, K. Ciołek, G. Ze studiów nad założeniami ogrodowymi Wołynia. Biuletyn Historii Sztuki i Kultury, 1939, vol. VII, iss. 1, p. 19-46.

52. Zielonko, A. Zazielenienie osiedli. Przeglad Ogrodniczy, 1935, iss.18, p. 203-204.

53. Zug, S.B. Ogrody $w$ Warszawie i jej okolicach opisane $w$ r. 1784; with notes by F.M. Sobieszczański, In: Kalendarz Powszechny na rok przestępny 1848, Y.14, p. 1-18.

\section{INFORMATION ABOUT THE AUTHOR:}

Agata Zachariasz - Dr hab. inż. arch., professor of Institute of Landscape Architecture, Faculty of Architecture, Cracow University of Technology. Adress: 31-155 Kraków, ul. Warszawska 24. E-mail: azachar@pk.edu.pl

Kopsavilkums. Pētījumā aplūkots laika periods no 19. gs. beigām līdz 20. gs. 50. gadiem. Rakstā atspoguḷoti poḷu ainavu arhitektūras pionieru panākumi, kas tiek asociēti ar vairākiem dizaina, plānošanas, vides aizsardzības un profesionālās izglītības aspektiem.

Lielākajā daḷā Eiropas valstu ainavu arhitektūras attīstība kā atsevišķu profesija ir datējama ar starpkaru periodu. Mūsdienās ainavu arhitektūra kā atsevišķa nozare Polijā netiek apšaubīta, tomēr vēl salīdzinoši nesen šis temats starp poḷu speciālistiem bija ḷoti diskutabls. Diskusijās iesaistījās dārzkopji, praktiḳi, zinātnieki un populisti no dažādākajām nozarēm, lai debatētu par profesiju un speciālistu sagatavošanu. Viens no pionieriem Zigmunts Helvigs (Zygmunt Hellwig), rakstīja: "Es ticu, ka ainavas veidošana ir māksla un zinātne, kas šobrīd ir pilnīgi patstāvīga, izaugusi līdzvērtīgi no dārzkopības, arhitektūras un citām līdzīgām nozarēm, kas vairs nevar ietilpt ēku arhitektūras profesionālās sagatavošanas un kvalifikācijas rāmjos.” (1935. g.) Ainavu arhitektūra kāa profesija attīstījās loti dinamiski. Tika izstrādāti nozīmīgi projekti, kas šobrīd tiek uzskatīi par ikoniskiem, piemēram, Železova Vola (Żelazowa Wola), pieminekḷu parks un Skarijsževki Parks (Skaryszewski Park) Varšavā. Dārzkopības gadatirgos lielu nozīmi ieņēma dārzu plānošana. Pilsētas lepojās ar sasniegumiem, veidojot publiskos parkus. Universitātes izglītības programmā iekḷāva ainavu arhitektūru kā atsevišķu profesiju. Francisžeks Krzivda-Polkovkis (Franciszek Krzywda-Polkowski), kas bija guvis izglītību kā arhitekts, bija pirmais, kas iekḷāva aianvu arhitektūru universitātes mācību programmā, organizēja un pārvaldīja Ainavu Arhitektūras un Parku Zinātnes nodaḷu Dabaszinātṇu Universitātē no 1928, gada. Viṇš pasniedza lekcijas Varšavas Tehnolog̣iju Universitātē. Viņa studenti Alina Šoltza (Alina Scholtz) un Gerards Cioḷeks (Gerard Ciołek) deva ievērojamu ieguldījumu Polijas ainavu arhitektūras attīstībā. 